\title{
The Effect of Epidermal Growth Factor (EGF) on Progestin Secretion and Cyclic AMP Synthesis in Cultured Luteal Cells from Pregnant Rats
}

\author{
Satoko ARAKAWA, Satoshi ISOBE, Hiroyuki MORI, Akira KAMbEGAWA, \\ RYUICHI KAN, SHOICHI OKINAGA AND KIYOSHI ARAI
}

Department of Obstetrics and Gynecology, Teikyo Univesity School of Medicine 2-11-1 Kaga Itabashi-ku, Tokyo, Japan

\begin{abstract}
It is reported that steroid synthesis in ovarian cells is affected by epidermal grow th factor (EGF). We cultured luteal cells from pregnant rats for 2 days with or without EGF, followed by incubation of the cells with or without stimulants (hCG, forskolin and dibutyryl cyclic AMP) for 5 hours. The levels of progesterone, 20 $\alpha$-hydroxy-pregn-4-en-3-one (20 $\alpha$-dihydroprogesterone) and cyclic AMP (cAMP) in the media were assayed. EGF had no effect on the basal levels of progesterone, 20 $\alpha$-dihydroprogesterone and cAMP, but it suppressed these levels which were increased by the stimulants.

We investigated binding capacity of $\left.{ }^{[25} \mathrm{I}\right]-\mathrm{EGF}$ to ovarian tissue of pregnant rats. Ovarian tissue had specific binding sites for EGF. The maximum number of bindihg sites was $2.38 \mathrm{fmol} / \mathrm{mg}$ tissue and the $\mathrm{Kd}$ value was $0.547 \mathrm{nM}$.

It was indicated that EGF modified the reactivity of luteal cells to stimulants; counteracting the tropic effect of gonadotropins. It was shown that this effect of EGF might be exerted through its receptor in luteal cells.
\end{abstract}

Steroidogenesis in rat ovarian cells is, at least in part, controlled by the epidermal growth factor (EGF). Jones et al. (1982) and Trezeciak et al. (1987) reported that EGF increased the progesterone release from rat granulosa cells but Zhiwen et al. (1987) showed the opposite result. There is also a report indicating that EGF either increases or decreases progesterone under different conditions (Knecht and Catt, 1983). In contrast to granulosa cells, we have little information about luteal cells and EGF. The present study was undertaken to investigate the effect of EGF on the synthesis of progesterone, 20 $\alpha$-hydroxypregn-4-en-3-one (20 $\alpha$-dihydroprogesterone) and cyclic AMP (cAMP) in luteal cells of pregnant rats. Specific binding sites of EGF in ovarian tissue from pregnant rats were also studied. 


\section{Materials and Methods}

\section{Chemicals}

DNAse (type I), follicle stimulating hormone (FSH, porcine), 3-isobutyl-1-methyl-xanthine (IBNX), forskolin, dbcAMP, bovine serum albumin (BSA, fraction V). trypsin and EGF (mouse) were purchased from Sigma Chemical Company (St. Louis, MO, USA). Calcium-andmagnesium-free Hanks' balanced salt solution (HCMF), HAM F-12 and Dulbecco's modified Eagle medium (DMEM) were obtained from Grand Island Biological Co. (Grand Island, NY, USA). Collagenase (type I; $137 \mathrm{U} / \mathrm{mg}$ ) was a product of Worthington Biochemical Co. (Freeland. NJ, USA). Insulin (human) was provided by Peptide Institute (Osaka, Japan). Multiple stimulating activity (MSA) was purchased from Collaborative Research (Bedford, Mass, USA). Human chorionic gonadotropin (hCG) was obtained from Teikoku Hormone Co. (Tokyo, Japan). $\left[{ }^{125} \mathrm{I}\right]$-EGF (mouse, $7.4 \mathrm{MBq} / \mu \mathrm{g}$ ) was a produt of New England Nuclear Corp. (Boston, MA, USA).

\section{Ovarian Cell Preparation}

Pregnant rats of the Wistar-Imamichi strain were sacrificed by decapitation on day 13 of gestation. Ovaries were dissected out and the surrounding tissue was removed. Each ovary was cut into 5-6 pieces and washed with HCMF containing 1\% BSA.

Cells were dispersed by incubating tissue pieces in HCMF containing $0.4 \%$ collagenase, $10 \mu \mathrm{g} / \mathrm{ml}$ DNAse, and $1 \%$ BSA for $60 \mathrm{~min}$ at $37^{\circ} \mathrm{C}$. The dispersed ovarian cells were collected by centrifugation (1000 rpm, $5 \mathrm{~min})$ and washed twice in HCMF. Aliquots of the cell suspension were diluted with equal volumes of Trypan blue stain and samples were taken for counting in a hemocytometer.

\section{Cell Culture Procedure}

Ovarian cells $\left(1 \times 10^{5}\right.$ viable $)$ were cultured in DMEM in a tissue culture plate (Corning, with 24 wells). The cells were cultured for 2 days with EGF to count the number of cells. In another series of experiments, the effect of the combined use of insulin on the number of cells was examined in a 6 day culture. To find out the effect of stimulants, the cells were cultured for 2 days with increasing doses of EGF and, after changing media, they were further incubated in HAM F-12 medium containing $100 \mathrm{IU} / \mathrm{ml} \mathrm{hCG}, 1 \times 10^{-6} \mathrm{M}$ forskolin, $1 \times 10^{-3} \mathrm{M}$ dbcAMP or $4 \times 10^{-4} \mathrm{M}$ IBMX. After $5 \mathrm{~h}$ of incubation, media were collected and stored at $-20^{\circ} \mathrm{C}$ until radioimmunoassay (RIA) was performed for progesterone, $20 \alpha$-dihydroprogesterone and cAMP. To confirm cell viability the culture media were replaced with HCMF containing $0.25 \%$ Trypsin and incubated for $40 \mathrm{~min}$ at $37^{\circ} \mathrm{C}$. Aliquots of the cell suspension were diluted with equal volumes of Trypan blue stain and viable cells were counted with a hemocytometer.

\section{RIA of progesterone, 20a-dihydroprogester- one and $C A M P$}

Steroids in the media were measured directly by RIA. Specific antibodies to progesterone and $20 \alpha$-dihydroprogesterone were raised in our laboratory; Japanese albino rabbits were immunized with injections of progesterone-11 $\alpha$ hemisuccinate-BSA or $20 \alpha$-dihydroprogesterone3-oxime-BSA and produced specific antisera. The cross-reactions of the anti-progestrone antibody (diluted at $1: 200,000$ ) to $20 \alpha$-dihydroprogesterone and of the anti-20 $\alpha$-dihydroprogesterone antibody (diluted at $1: 5000$ ) to progesterone were $6.73 \%$ and $4.40 \%$ respectively (Yoshida et al., 1973; Tanemori et al., 1977). cAMP in the media was measured with the Yamasa (Chosi, Japan) cyclic AMP kit.

\section{EGF binding to rat ovarian homogenate}

Pregnant rats of the Wistar-Imamichi strain were sacrificed by decapitation on day 13 of gestation. Ovaries were homogenized in a teflon glass homogenizer with $25 \mathrm{mM}$ tris- $\mathrm{HCl}$ buffer containing $10 \mathrm{mM} \mathrm{MgCl}{ }_{2}$ and $0.1 \%$ BSA (pH 7.4). Homogenate was diuted with buffer to $50 \mathrm{mg}$ tissue $/ \mathrm{ml}$ and stored at $-80^{\circ} \mathrm{C}$ until the binding assay was performed. To a small test tube $350 \mu 1$ of buffer, $50 \mu 1$ of homogenate and $100 \mu \mathrm{l}$ of $\left[{ }^{125} \mathrm{I}\right]$-EGF (about $1 \times 10^{4}-2 \times 10^{6}$ $\mathrm{dpm})$ were added, mixed, well and incubated for 1 hour at $37^{\circ} \mathrm{C}$. To rule out non spesific binding, $500 \mathrm{ng}$ of EGF was added to the control incubation tubes. After incubation the tubes were centrifuged at $3000 \mathrm{rpm}$ for $10 \mathrm{~min}$ and the supernatant containing free $\left[{ }^{125} \mathrm{I}\right]-\mathrm{EGF}$ was removed. The precipitate was washed twice with assay buffer. $\left[{ }^{125} \mathrm{I}\right]$-EGF bound to the precipitate was counted in a gamma spectro- 
meter (Aloka, ARC-600). The data were analysed by Scatchard, plot (Scatchard 1949) and the maximal number of binding sites (Bmax) and Kd were calculated. Replacement of the labelled EGF with other peptide hormones was investigated.

\section{Statistical Analysis}

Statistical analysis of the results was made by the Student's $t$-test and a P value of less than 0.05 was considered significant.

\section{Results}

\section{The Number of cells}

In a 2 day culture, $1-100 \mathrm{ng} / \mathrm{ml}$ of EGF had no effect on the number of cells (Fig. 1 a). In a 6 day culture $100 \mathrm{ng} / \mathrm{ml}$ of insulin increased the number of cells but the increase was not significant (Fig. $1 \mathrm{~b})$. When $10 \mathrm{ng} / \mathrm{ml}$ of EGF was added, insulin increased the number of cells significantly $(\mathrm{P}<0.05)$. EGF by itself had no effect on the number of cells in a 6 day culture.

\section{The Levels of progesterone, 20a-dihy-} droprogesterone and $\mathrm{CAMP}$ in the Culture Medium

The increase in progesterone by forskolin $(\mathrm{P}<0.01)$ and dbcAMP $(\mathrm{P}<0.001)$, that of $20 \alpha$-dihydroprogesterone by forskolin $(\mathrm{P}<$ $0.05)$ and that of cAMP by hCG $(P<0.05)$ without IBMX were significant. With IBMX added, the increase in progesterone by $\mathrm{hCG}$ $(\mathrm{P}<0.001)$, forskolin $(\mathrm{P}<0.01)$ and dbcAMP $(\mathrm{P}<0.001)$, that of $20 \alpha$-dihydroprogesterone by dbcAMP $(\mathrm{P}<0.001)$ and that of cAMP by hCG $(\mathrm{P}<0.001)$ and forskolin $(\mathrm{P}<0.001)$ were significant (Fig. 2 a).

EGF had no effect on the basal progesterone, 20 $\alpha$-dihydroprogesterone and cAMP concentrations after a 2 day culture (Fig. 2b). However, when these cells had been precultured with EGF and were further incubated for 5 hours with stimu- lants, the stimulated output of progesterone by forskolin or dbcAMP, and of $20 \alpha$ dihydroprogesterone by hCG or forskolin was suppressed significantly by EGF (Fig.

Fig. 1 a

$$
\left(\times 10^{4}\right) \quad 2 \text { days culture }
$$

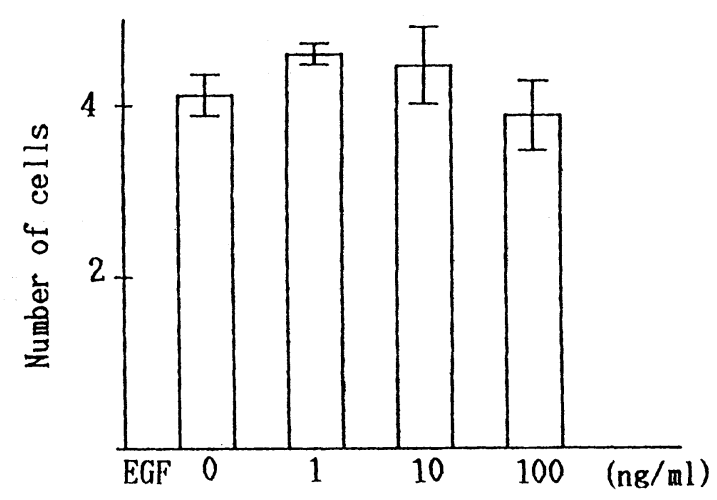

Fig. 1 b

6 days culture

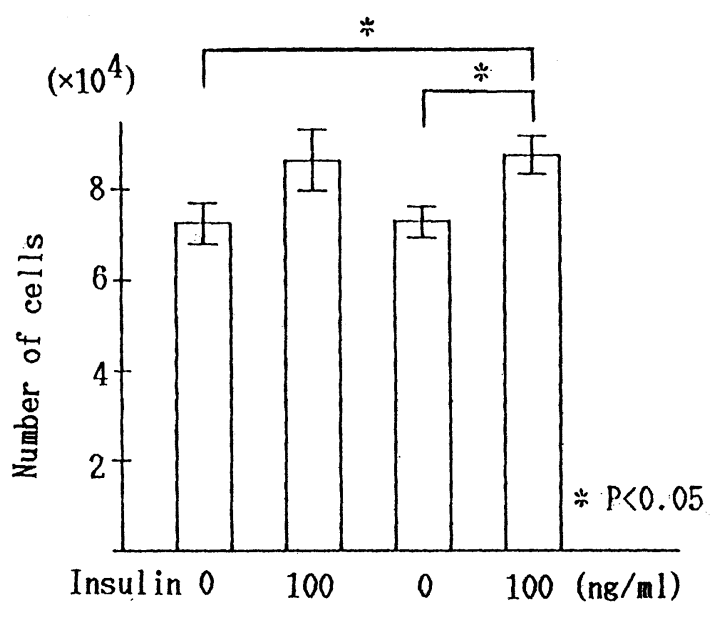

$\begin{array}{lllll}\text { EGF } & 0 & 0 & 10 & 10\end{array}$

Fig. 1. The number of cells after 2 (Fig. 1 a) or 6 days' (Fig. 1 b) culture with EGF or insulin and EGF. The vertical bars indicate standard errors. 
Fig. 2 a

The effect of the stimulants
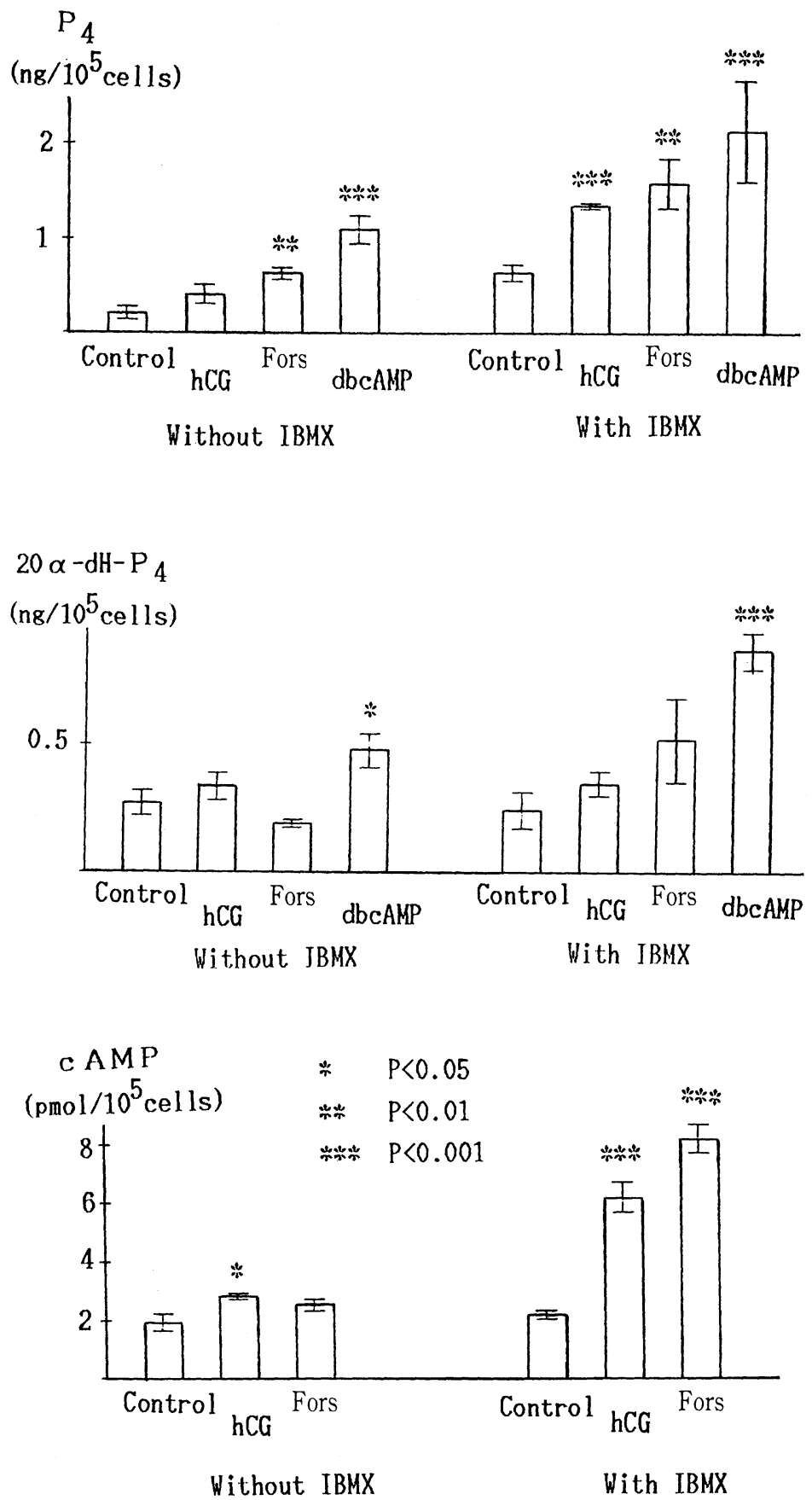

Fig. 2. The luteal cells cultured for 2 days with increasing doses of EGF. After the media were changed they were further incubated with or without stimulants (hCG, forskalin, dbcAMP) for 5 hours. This figure shows the levels of $\mathrm{P}_{4}, 20 \alpha$-dH-P and cAMP in the medium after 5 hours' incubation. The effect of the stimulants on $\mathrm{P}_{4}, \quad 20 \alpha$-dH- $\mathrm{P}_{4}$ and cAMP concentrations (Fig. 2 a). The incubation was performed in the absence (Fig. 2 b) or presence (Fig. $2 \mathrm{c}$ ) of IBMX. The vertical bars indicate standard errors. The abbreviations are as follows. $\mathrm{P}_{4}$ : Progesterone, $20 \alpha$-dH$\mathrm{P}_{4}: 20 \alpha$-dihydroprogesterone, Fors : Forskolin. 
Fig. 2 b

Without IBMX

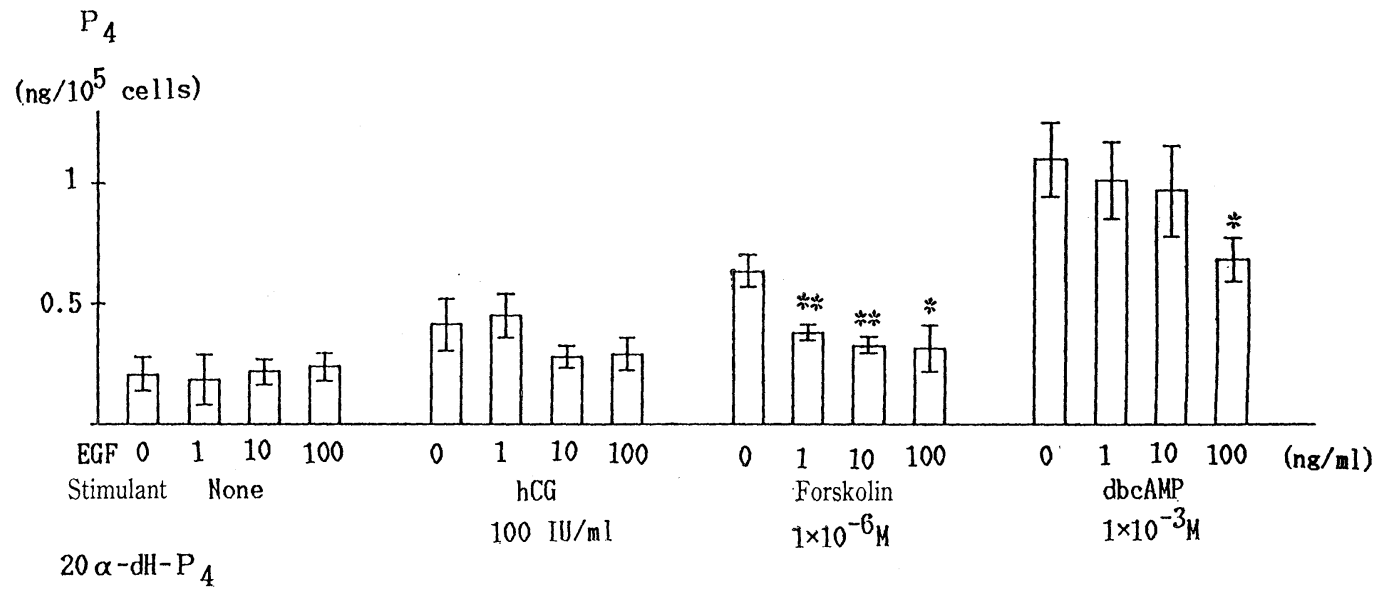

(ng/10 $0^{5}$ cells)

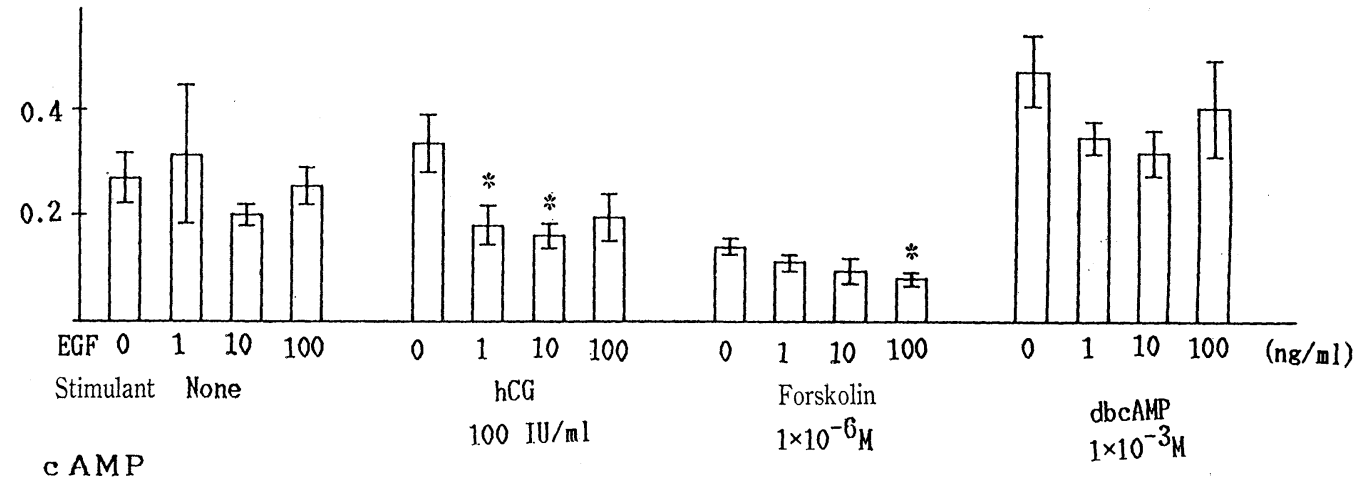

(pmol/10 $10^{5}$ cells)

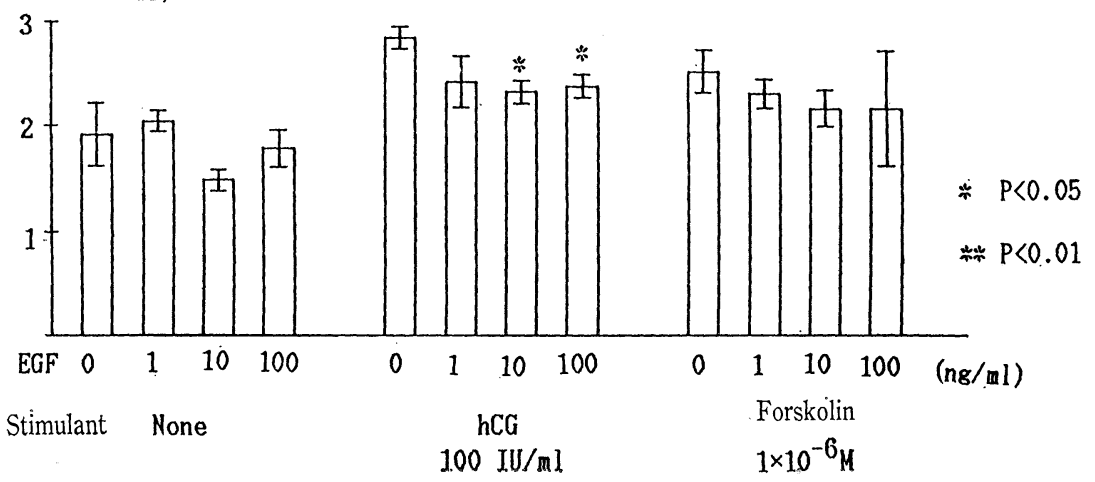


Fig. 2 c

With IBMX

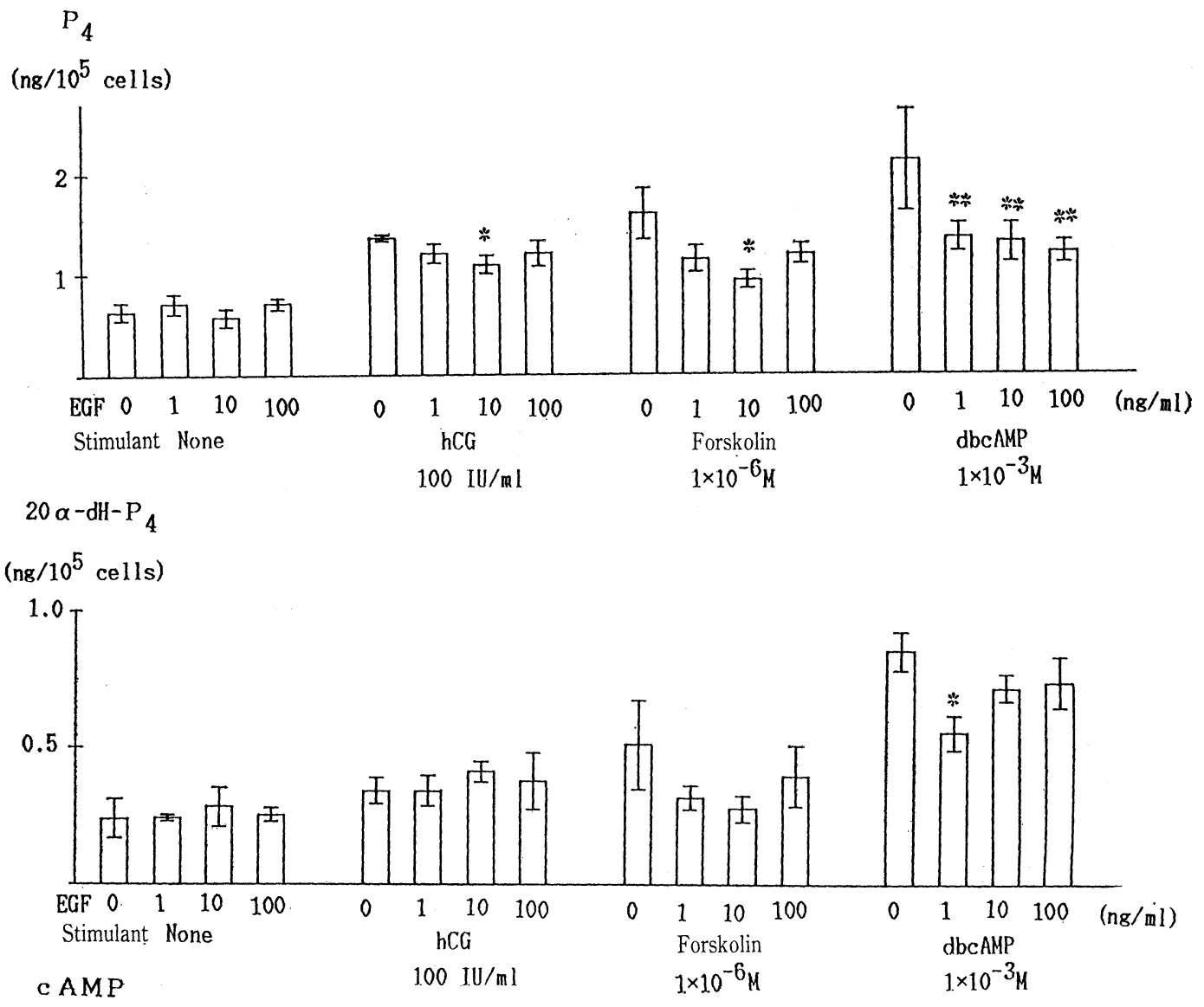

(pmol/105 cells)

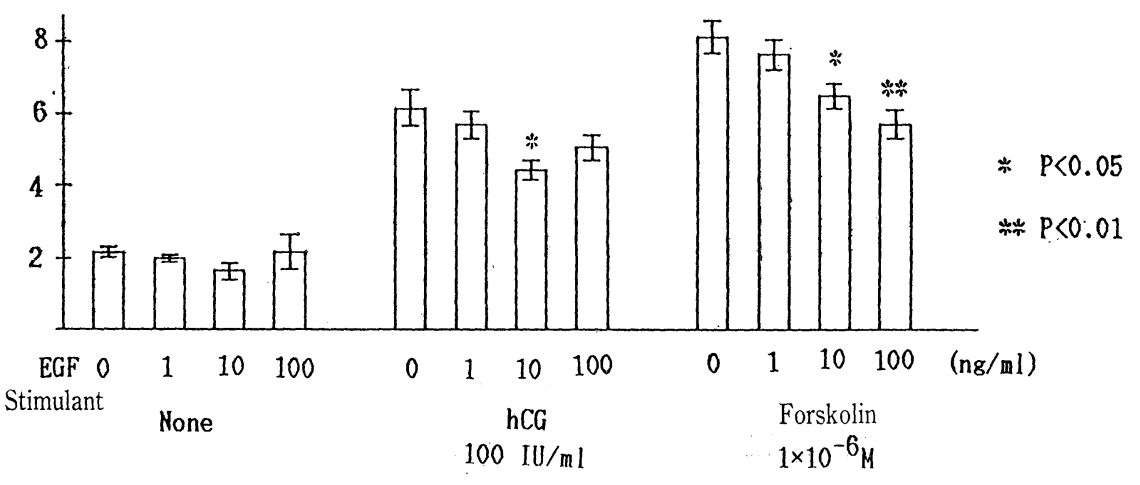


$2 \mathrm{~b})$. EGF also significantly decreased the level of cAMP in the medium when the cells were stimulated by hCG. The minimum effective dose of EGF counteracting the increased output of progestins was $1 \mathrm{ng} / \mathrm{ml}$. A similar result was obtained when cells had been incubated in the presence of IBMX for 5 hours; EGF canceled the increased output of progesterone by hCG, forskolin and dbcAMP, that of $20 \alpha$-dihydroprogesterone by dbcAMP, and that of cAMP by hCG and forskolin. EGF had no effect on the basal progesterone, $20 \alpha$-dihydroprogesterone and cAMP concentrations, but decreased their reactivity to the stimulants (Fig. $2 \mathrm{c}$ ).

\section{EGF Binding to Rat Ovarian Homo- genate}

The specific binding sites for EGF with high affinity and low capacity were confirmed in ovarian luteal tissue (Fig. 3 a). The $\mathrm{Kd}$ value of the ovarian EGF specific binding sites was $0.55 \mathrm{nM}$ and $B \max$ was $2.38 \mathrm{fmol} / \mathrm{mg}$ tissue (Fig. $3 \mathrm{~b}$ ). The competition assay data showed that the binding sites were specific to EGF (Fig. $3 \mathrm{c}$ ). The [125I]-EGF binding to the tissue preparation was not inhibited by insulin, MSA, FSH or hCG.

\section{Discussion}

The present study showed that under certain circumstances EGF counteracted the stimulating effect of $\mathrm{hCG}$, forskolin and dbcAMP to release progesterone, $20 \alpha$-dihydroprogesterone and cAMP from cultured luteal cells of pregnant rats.

EGF also counteracted the effect of hCG to increase the release of cAMP (Fig. $2 \mathrm{~b}$ ). The same results were obtained with IBMX added in the media (Fig. 2 a); this effect may be due to a decrease in the synthesis of cAMP rather than an increase in phosphodiesterase. Synthesis of ovarian steroids is a cAMP dependent process. EGF decreased the progesterone release stimulated by dbcAMP either with or without IBMX in the media (Fig. 2b, c). Consequently, it may be postulated that EGF suppresses the release of progestins through the decrease in synthesis of cAMP and of sensitivity to cAMP. EGF decreases the cAMP release in rat granulosa cells (Knecht and Catt, 1983; Feng et al., 1986) and also decreases the hCG receptors increased by 8-bromo-cAMP (Knecht and Catt, 1983). These reported results are in agreement with our present findings.

EGF decreased the levels of progesterone increased by the stimulants. This is due to the decrease in progesterone synthesis rather than the increase in the activity of $20 \alpha$-hydroxylase because the level of $20 \alpha$ dihydroprogesterone was also decreased by EGF.

In the present study, EGF did not increase the number of luteal cells cultured in vitro. Similar results have been reported by several investigators in rat granulosa cells (Jones et al., 1982; Zhiwen et al., 1987; Feng et al., 1986). EGF may have little effect on the proliferation of luteal or granulosa cells.

It is possible that the toxic effect of EGF decreased the synthesis of progestins and cAMP. But this is not likely, because $10 \mathrm{ng} / \mathrm{ml}$ of EGF did not inhibit the effect of insulin to induce cell proliferation (Fig. $1 \mathrm{~b})$.

The rat corpus luteum (Chabot et al., 1986), theca cells (Feng et al., 1987; Chabot et al., 1986) and granulosa cells stimulated by FSH (Feng et al., 1987; Chabot et al., 1986) have the EGF receptor. In the present study we confirmed that the corpus luteum of pregnant rats had saturable EGF binding sites with high specificity and affinity, namely the EGF receptor. It is possible that the receptor we detected may party be located in non luteal cells. In fact, Chegini et al., (1989) found a 
Fig. 3a

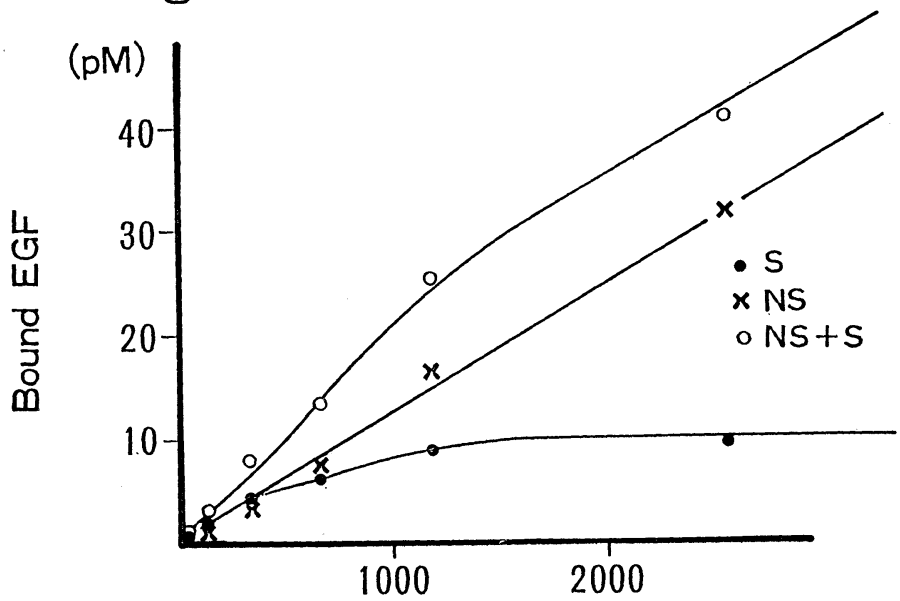

Fig. 3b Total EGF (pM)

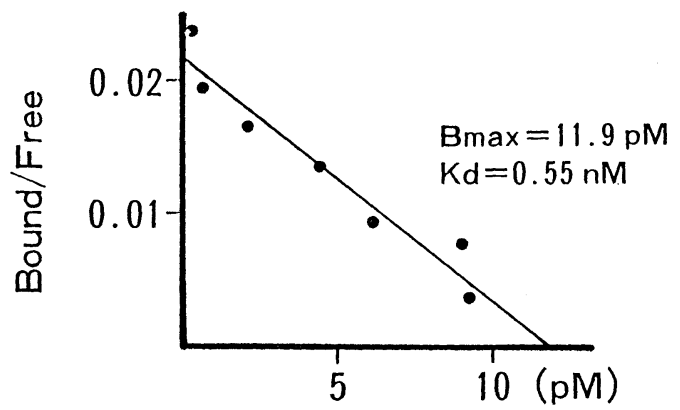

Fig. 3c

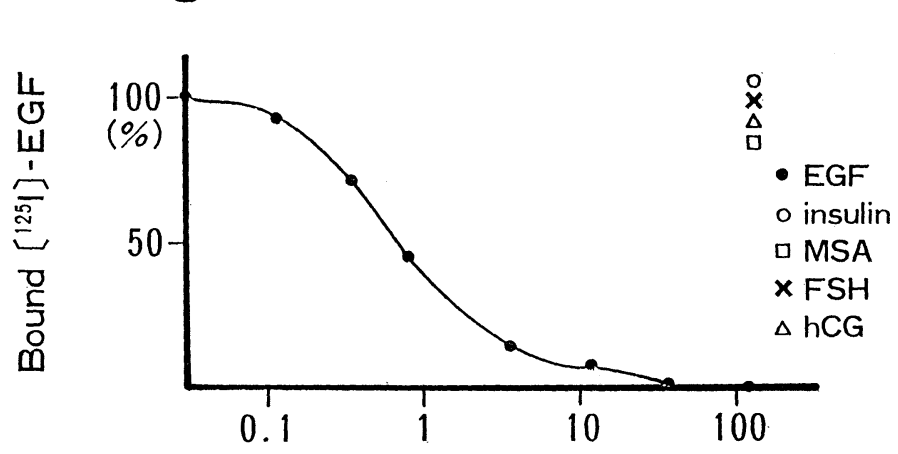

Cold peptide $/\left[{ }^{125} \mid\right]-E G F$

\section{Bound EGF}

Fig. 3. Binding assay of EGF to Rat ovarian homogenate. Fig. 3 a shows total, nonspecific (NS) and specific (S) binding of EGF to rat ovarian tissue. Fig. $3 \mathbf{b}$ is the Scatchard plot derived from specific binding of EGF. Fig. $3 \mathrm{c}$ shows the competition assay of EGF and other peptide hormones. The dose of $\left[{ }^{125} \mathrm{I}\right]-\mathrm{EGF}$ was $0.413 \mathrm{ng} /$ tube. 
larger number of binding sites of EGF in bovine small luteal and non luteal cells than in large luteal cells. EGF has the potential to regulate ovarian functions through its receptor. Reportedly, the $\mathrm{Kd}$ value of the EGF receptor from rat granulosa cells is $5.7-5.4 \times 10^{-11} \mathrm{M}$ (Feng et al., 1987). If the tissue preparation is taken from rats at random stages of the estrous cycle, the $\mathrm{Kd}$ value is $1.1 \times 10^{-9} \mathrm{M}$ (Kelly and Labrie, 1983). Our present experiment showed that this value was $5.5 \times 10^{-10} \mathrm{M}$. The difference may be due to different experimental conditions. Further studies will be needed to clarify these points.

Richardson et al. (1989) reported that EGF increased the progesterone release from cultured human granulosa lutein cells. Conflicting results may be due to species differences or the biphasic effects of EGF.

It is concluded that EGF suppressed the release of progestins induced by stimulants in luteal cells from pregnant rats and this effect was most likely exerted via the ovarian EGF receptor.

\section{References}

Arnaud, R. ST-, P. Walker, P. A. Kelly and F. Labrie (1983). Rat Ovarian Epidermal Growth Factor Receptors : Characterization and Hormonal Regulations. Mol. Cell Endocrinol. 31, 43-52.

Chabot, J. -G., R. St-Arnaud, P. Walker and G. Pelletier (1986). Distribution of Epidermal Growth Factor receptors in the Rat Ovary. Mol. Cell Endocrinol. 44, 99-108.

Chegini, N., Z. M. Lei and C. V. Rao (1989). Light and Electron Microscope Immunocytochemical Localization of Epidermal Growth Factor Receptors in Bovine Corpola Lutea of Pregnancy. In: Growth Factors and the Ovary (A. N. Hirshfield ed.), Plenum Press, New York. pp. 213-220.

Feng, P., M. Knecht and K. Catt (1987).
Hormonal Control of Epidermal Growth Factor Receptors by Gonadotropins during Granulosa Cell Differentiation. Endocrinology 120, 1121-1126.

Feng, P., K. J. Catt and M. Knecht (1986). Transforming Growth Factor $\beta$ Regulates the Inhibitory Actions of Epidermal Growth Factor during Granulosa Cell Differentiation. J. Biol. Chem. 261, 14167-14170.

Jones, P. B. C., T. H. Welsh Jr. and A. J. W. Hsueh (1982). Regulation of Ovarian Progestin Production by Epidermal Growth Factor in Cultured Rat Granulosa Cells. $J$. Biol. Chem. 257, 11268-11273.

Knecht, M. and K. J. Catt (1983). Modulation of cAMP-mediated Differentiation in Ovarian Granulosa Cells by Epidermal Grow th Factor and Platelet-derived Growth Factor. J. Biol. Chem. 258, 2789-2794.

Richardson, M. C., S. C. Gadd and G. M. Musson (1989). Augmentation by Epidermal Growth Factor of Basal and Stimulated Progesterone Production by Human Luteinized Granulosa Cells. J. Endocrinol. 121, 397402.

Scathard, G. (1949). The Attractions of Proteins for Small Molecules and Ions. Ann. New York. Acad. Sci. 51, 660-672.

Tanemori, K., Y. Horiuchi, H. Ozaki, T. Yoshida, S. Takagi, A. Kambegawa, T. Shinohara and T. Kokubu (1977). RIA of $20 \alpha$-hydroxy pregn4-en-3-one. Hormone and Clinic 25, 303-308. (in Japanese)

Treciak, W. H., T. Duda, M. R. Waterman and E. R. Simpson (1987). Effects of Epidermal Growth Factor on the Synthesis of the Cholesterol Side-chain Cleavage Enzyme Complex in rat Ovarian Granulosa Cells in Priming Culture. Mol. Cell Endocrinol. 52, 43-50.

Yoshida, T., K. Den, H. Mukai, M. Noda, S. Takagi, T. Makino and A. Kambega wa (1973). Radioimmunoassay of Sex Steroid Hormone (V). Horumon to Rinsho 21, 979-985. (in Japanese)

Zhiwen, Z., A. C. Herington, R. S. Carson, J. K. Findlay and H. G. Burger (1987). Direct Inhibition of Rat Granulosa Cell Inhibin Production by Epidermal Growth Factor in vitro. Mol. Cell Endocr. 54, 213-220. 